\title{
Development of Indices for Effectiveness of Renewable Energy Technologies Impacting Change in Quality of Life of Rural Residents
}

\author{
Supriya*1, Sushma Goel ${ }^{2}$, Pradeep Chandra Pant ${ }^{3}$ \\ ${ }^{1} \mathrm{PhD}$ Scholar, Lady Irwin College, University of Delhi, Sikandra Road, New Delhi, India \\ ${ }^{2}$ Associate Professor, Lady Irwin College, University of Delhi, Sikandra Road, New Delhi, India \\ ${ }^{3}$ Director/Scientist 'F', Ministry of New and Renewable Energy, Government of India, New Delhi, India
}

\begin{abstract}
The history of economic development is on the cost of ecology rather than the sustaining environment and development. The countries that became centrally located in the stream of economic exchanges among people around the world impacted the environment in the long run. Newspapers and editorials include environmental horror stories almost on a daily basis and demand better management of natural resources (Jangu, 2014). But who is listening?
\end{abstract}

The environment is not just lush green trees, threated plant and animal species. It is the entity on which humans primarily exist, and agricultural and industrial development depends. Development on the cost of the environment can never be sustainable rather it would take us to a point causing enormous ecological losses and human sufferings primarily because of the present rate of development in developing countries. In order to contribute to the overall development in India, access to modern energy and cleaner fuel for rural households is important. The Brundtland Commission in its 1987 report 'Our Common Future' coined the most quoted definition of the term sustainable development, i.e., development that meets the needs of the present without compromising the ability of the future generations to meet their own needs (Mathur and Goswami, 2016). Sustainable production and consumption of resources helps to satisfy necessities of life such as nutritious food, good health, clean water and sanitation, clean energy, education, employment creating sustainable communities while combating climate change.

Having a negative energy balance for decades, India is forced to purchase energy from other countries to fulfil the needs of the entire country. Hence, energy access is an important component of poverty alleviation and an indispensable element of sustainable human development. Government of India has initiated numerous development programmes focussing on providing sustainable energy solutions to rural communities often deprived of clean and uninterrupted energy supply for their daily energy requirements. The study entitled 'Renewable Energy
Options among Rural Households' was conducted in Haryana and Himachal Pradesh states. The outcomes of the study provide a roadmap for future programmes promoting the use of clean, efficient and modern energy technologies, to be implemented more effectively. Findings would further benefit the primary and secondary key stakeholders involved in research and development, formulation of policies and regulations, promoting sale and purchase and provide financial assistance to future energy programmes meant to popularize the use of Renewable Energy Technologies.

Keywords - Renewables, Sustainable energy, Rural households, Energy-use pattern, Solar energy.

\section{INTRODUCTION}

Energy is fundamental to survival of life in any part of the globe. The pervasive nature of energy related activities have vast impact on the environment world over. With the current pattern of energy production, distribution and consumption, the resources will be exhausted much faster that would cause accelerated environmental degradation and slow down the progress dramatically. The energy sector has to play a critical role, especially in developing countries due to the huge investments required to meet the growing energy needs.

For the present research the categorization of energy resources used is Non-Renewable and Renewable energy resources. Non-renewable Energy Resources refer to those sources of energy that are derived from finite and static stock of energy. They cannot be produced, grown, generated or used on a scale that can sustain its consumption rate. The fossil fuels such as coal, petroleum, natural gas, nuclear power are examples of non-renewable sources of energy. Renewable Energy Resources refer to those resources which are available in abundance, are infinite and environment friendly in nature. These resources include solar, wind, biomass, wave and tidal energy (Varun and Chauhan, 2014).

Energy Access to Rural Households in India 
India has transitioned from being the world's seventhlargest energy consumer in 2000 to fourth-largest within a decade and is the fifth largest power generators worldwide. India's energy basket has a mix of all the resources available including renewable energy resources (Pawar and Kaur, 2014).

Among the various sectors that use energy, household sector is the largest consumer of energy. Rural Households (HHs) in developing countries are often dependent on the use of traditional biomass resources such as fuel wood, crop residue and dung cakes for activities such as cooking, domestic lighting, water heating, cattle-feed preparation and indoor space heating. It provides for a minimum lifesupporting energy service and also represents a high financial cost, negative effects on human health and stress on environmental resources.

There are many impediments to energy access for the rural masses despite the launch of several programmes and policies by the Government that aim to improve quality of life of people living in the remote and rural areas of the country. Some of these barriers are geographicallydispersed villages that are difficult to reach and hence, providing electricity (through conventional electric grid) becomes difficult. There is inadequate focus to explore local energy resources either due to lack of funds, technological know-how and appropriate organization. Adequate financial models to tap resources through PublicPrivate Partnership (PPP) are inadequate. Private sector investment is not sufficiently facilitated by the Government through an appropriate mix of subsidies and grants; incentives and tariff policies; and risk sharing. Due to low population density and fewer households in rural areas there is high transmission cost along with severe transmission and distribution losses. The lack of facility for domestic connection in initial stages, uncertainty of power, load has impacted the demand for power in rural area due to poor quality and unavailability. Long and cumbersome procedures for getting a connection, distant location of facilities for paying bills and repair affect acceptability of renewable energy resources (Kumar, 2012).

\section{Need to Shift to Renewable Energy Technologies (RETs)}

Traditional solutions often comprise relatively low efficiency and much of the energy output gets wasted due to use of age-old (inefficient) technologies. Therefore, sustainable energy services are seen as a necessity for improving the standard of living, facilitating development and reducing environmental impact. Use of decentralized and small-scale technologies that make use of new, locally available, renewable resources such as sun, biomass, wind, water etc. appear to be the ultimate solution. RETs can provide universal modern energy services which drive development and improve living conditions, particularly in rural communities (Mahapatra and Dasappa, 2012).

As mentioned by Kumar et al (2010), to meet the energy requirement for such a fast growing economy, India will require an assured supply of three to four times more energy than the total energy consumed today. RETs are being progressively adopted as an alternative to conventional energy resources to ensure a sustainable future. In India there has been vigorous pursuit of activities related to production, application, research and development, demonstration and awareness for a variety of RETs to be used in different sectors. The benefits of access to clean energy resources for rural areas are many, including reduced deforestation and carbon emissions; improved healthcare services due to reduced consumption of raw water and smoke from open fire cooking; clean energy generated from renewable resources; decreased use and dependency on kerosene, wood and coal; improved agricultural output and access to potable and clean water. Renewable energy sources create a momentum for increasing time available for productive, income generating tasks and wealth creation over time. This can help in poverty reduction in rural communities (Chaurey et al, 2004).

\section{METHODOLOGY}

The study was conducted in villages/hamlets from four districts of two states, viz-a-viz., Faridabad and Panchkula districts (Haryana); and Hamirpur and Bilaspur districts (Himachal Pradesh). The selection criterion for villages/hamlets for study was the presence of residents using RETs, i.e., either possessing or benefitting from RETs (since two or more than two years). The villages/hamlets from Haryana and HP were selected as the locale of the study because of presence of HHs using similar types of RETs in both the states, there was availability of solar grid in Haryana for electrification of HHs that provided an opportunity to the researcher to understand the effect of electricity on their quality of life. Few hamlets that were close to the border of HP, also benefitted from the solar electrification programme of Haryana. This gave an opportunity to compare the ownership and usage of RETs in both the states.

The ex-post facto research design included qualitative analysis and interview of the stakeholders, vis-à-vis., RET users, village representatives and RET programme implementation officers from Akshay Urja (AU) shops. Purposive Sampling Technique was used to select the key stakeholders for the study (i.e., RETs programme implementation officials, RET users and village representatives).To get an insight about the location of houses using RETs, community service and facilities, sources of biomass collection etc., resource maps were 
prepared by involving the village representatives, residents and programme implementation officials (field staff from $A U$ shops and local repair technicians).

\section{Significance of the Study}

Achievement of goals at an individual, community and world level are possible only if access to affordable and reliable energy for rural areas is available. This would help to strengthen jobs, enhance security, provide hygienic food, increase income, help in betterment of health and education. United Nations have been working with Governments to ensure the sustainable development across the countries. Millennium Development Goals (MDGs) launched in 2000 primarily focussed on ensuring environmental sustainability by integrating the principles of sustainable development into country policies and programmes and reverse the loss of environmental resources (Goal 7A). Though there was no MDG specifically mentioning energy access and security. Building on the success and momentum of MDGs a smooth transition to the new global goals, i.e., Sustainable Development Goals (SDGs) launched in $2015 \mathrm{had}$ proposed to confront the energy issues directly. These cover the three dimensions of sustainable development, namely, economic growth, social inclusion and environmental protection. In addition, these 17 SDGs are universal and apply to all countries, unlike MDGs that were intended for action in developing countries only. Each goal has specific targets that have to be achieved over the next 15 years. Goals that focus specifically to energy access and mitigation of climate change are Goal 7 (Ensure access to affordable, reliable, sustainable and modern energy for all) and Goal 13 (Take urgent action to combat climate change and its impacts).

In India almost $68.84 \%$ of the population resides in rural areas (Census Report, 2011). Also, India has highest percentage $(35.4 \%)$ of population in the world that does not have access to the modern energy. Most of this population is from the rural areas of India. In addition, rural India is a power house of natural energy resources and provides great opportunity for production of renewable energy that can be utilized for the rural households, community at large and improving their built-environment such as schools and health centres. Also, improving the overall quality of life of residents w.r.t providing power to small businesses or cottage industries, income generation, financial security, health, education and reduction in drudgery of women. The research entitled Renewable Energy Technologies among Rural Households studied the energy use pattern in rural HHs of Haryana and HP; pointing towards two broad categories of resources used by rural households to fulfil their day-to-day energy requirements for various $\mathrm{HH}$ activities. These were Non-Renewable Energy Technologies (NRETs) and Renewable Energy Technologies (RETs).In light of this, the study proposes a Sustainable Development Model for Co-existence of NRETs and RETs that can helpto integrate efficient use of RETs and conservation of NRETs, to achieve the Sustainable Development Goals (SDGs). At the same time provide solution to the existing barriers in adoption and sustenance of new and modern technologies in rural communities.

\section{RESULTS AND DISCUSSION}

This chapter briefly focuses on the development of the indices for Effectiveness of RETs and Change in Quality of Life of Residents w.r.t RET Usage.

\subsection{Effectiveness of RETs Index}

\subsubsection{Rationale for Development of Index}

The RETs effectiveness index was developed for the following reasons-

(a) RETs had been installed, distributed and purchased by selected users under various Government programmes and schemes. To find out the performance of RETs, it was necessary to develop a scale that could evaluate the effectiveness concerning programme implementation and sustenance, ease of use and operation, product affordability, product design, repair and maintenance and reliability (refer Table 3.1).

Table.3.1: RETs Effectiveness Index Parameters and Sub-Parameters Developed for the Present Research

\begin{tabular}{|c|c|c|}
\hline S.No. & Effectiveness Parameters & Sub-Parameters \\
\hline 1 & Product Affordability & $\begin{array}{ll}\text { - } & \text { Presence of Subsidies } \\
\text { - } & \text { Loans and other incentives } \\
\text { - } & \text { Cost of RETs and components } \\
\text { - } & \text { Repair and Maintenance service costs }\end{array}$ \\
\hline 2 & Ease of Operation & $\begin{array}{ll}\text { - } & \text { Functioning and usage } \\
\text { - } & \text { Efforts to procure and install } \\
\text { - } & \text { Ease in transportation and storage } \\
\text { - } & \text { Availability of components } \\
\end{array}$ \\
\hline 3 & Repair and Maintenance & $\begin{array}{l}\text { - } \text { User competence to troubleshoot faults } \\
\text { - } \quad \text { Repair service/AU shops }\end{array}$ \\
\hline
\end{tabular}




\begin{tabular}{|c|c|c|}
\hline & & $\begin{array}{l}\text { - Availability of trained technicians } \\
\text { - } \quad \text { Response time }\end{array}$ \\
\hline 4 & Product Design & $\begin{array}{ll}\text { - } & \text { Aesthetic appeal } \\
\text { - } & \text { Recurrence of faults } \\
\text { - } & \text { Simple and standardized design }\end{array}$ \\
\hline 5 & Reliability & $\begin{array}{ll}\text { - } & \text { Supplementing NRETs } \\
\text { - } & \text { Utility } \\
\text { - } & \text { Durability } \\
\text { - } & \text { Predictable }\end{array}$ \\
\hline 6 & Initiation and Sustenance & $\begin{array}{ll}\text { - } & \text { Awareness generation } \\
\text { - } & \text { Community participation } \\
\text { - } & \text { Effective management } \\
\text { - } & \text { Equitable access } \\
\text { - } & \text { RETs waste management } \\
\text { - } & \text { Role of women }\end{array}$ \\
\hline \multicolumn{2}{|c|}{ Validity of Index } & $\begin{array}{l}\text { The validity of the index was attained through } \\
\text { Content Validity. }\end{array}$ \\
\hline \multicolumn{2}{|c|}{ Reliability of Index } & $\begin{array}{l}\text { Cronbach's (alpha) was calculated to measure the } \\
\text { internal consistency and reliability. The index had } \\
\text { high degree of internal consistency (Cronbach's } \\
\text { alpha: } 0.756 \text { ). }\end{array}$ \\
\hline
\end{tabular}

(b) There were very few existing tools present to measure effectiveness of RETs as they focused largely on ownership, utilization and working status of RETs. All of these researches focused on integrated rural development with the use of energy efficient technologies including individual and community RETs. The scales that had already been developed had to be adapted for use in the present study because they were either too lengthy, specific for urban users, covered few RETs or did not cover all relevant dimensions in the present situation as revealed in the pilot study. The pilot study pointed out that various RETs were used by the rural residents.

\subsubsection{Method of Development of Index}

Development of Effectiveness of RETs index was executed in the following stages:

- Concept clarification involved review of literature and consultation of experts to finalize definition of effectiveness and the dimension that impacted the effectiveness of RETs.

- Review of existing indices on effectiveness of RETs helped in determining the relevant dimensions to develop the 'effectiveness of RETs index'.

- Review of proposed 'Effectiveness of RETs index' by the experts.

\subsubsection{Selection of Parameters for RET Effectiveness Index}

Various experts reiterated parameters that would contribute to the overall effectiveness of RETs in a rural set-up. An in-depth analysis of different parameters covered for selected RETs was done and relevant dimensions were included in the effectiveness index. Table 3.2 depicts the various indices that had been referred for formulating the RETs Effectiveness Index relevant for the study. Amongst the Effectiveness indices studied, following three indices seemed relevant in the context of the present study:

(a) PV System Acceptance Test (2000): RETs Effectiveness Score cards developed by New Mexico State University's Southwest Technology Institute and Winrock International. These score cards had been developed to study the effectiveness of electrification of households using solar grid. It was a comprehensive tool that focused on use, operation, repair and maintenance services, community participation etc. that helped in contributing towards sustainability of the PV electrification programme. It also helped to identify issues that acted as barriers towards overall success of the programme.

(b) Village Energy Schedule (2002): India Rural Energy Study by UNDP (United Nations Development Programme) and ESMAP (Energy Sector Management Assistance Programme) sponsored by World Bank named Energy Strategies for Rural India: Evidence from Six States surveyed six states to provide a wide range of climatic,topographic and socio-economic development. They were Andhra Pradesh, Himachal 
Pradesh, Maharashtra, Punjab, Rajasthan, and West Bengal. The schedule focussed on aspects related to energy-use practices, adoption of modern energy, user awareness and willingness to adopt newer technologies and attitude towards Government policies and programmes.

(c) Village Level Schedule (2005): This was formulated by Technology Projects and Market Research Group (TPMRG). It was based on the project under Integrated Rural Energy Programme and MNRE on cluster of villages that consisted of questions pertaining ownership, functioning and usage of RETs by rural residents in selected villages of Haryana. Based on the findings suggestions were given regarding potential technologies and strategies to be followed to save conventional energy resources used by rural residents.

Since, each of these indices were specific for the purpose for which they were formulated, therefore, they seemed limited for the present study.

Table.3.2: Parameters of RETs Effectiveness Index Covered in Other Researches and Developed for the Present Research

\begin{tabular}{|c|c|c|c|}
\hline $\begin{array}{l}\text { PV System Acceptance } \\
\text { Test (2000) by New } \\
\text { Mexico State University } \\
\text { and Winrock } \\
\text { International }\end{array}$ & $\begin{array}{l}\text { Village Energy Schedule } \\
\text { (2002) by UNDP and } \\
\text { ESMAP }\end{array}$ & $\begin{array}{l}\text { Village Level Schedule } \\
\text { (2005) by Technology } \\
\text { Projects and Market } \\
\text { Research Group }\end{array}$ & $\begin{array}{l}\text { RETs Effectiveness parametersfor } \\
\text { the present study }\end{array}$ \\
\hline $\begin{array}{l}\text { 1. Effectively Sustained } \\
\text { Technology }\end{array}$ & $\begin{array}{l}\text { 1. Users Awareness and } \\
\text { Willingness towards } \\
\text { RETs }\end{array}$ & 1. Ownership of RETs & $\begin{array}{l}\text { 1. Product Affordability } \\
\text { - Presence of Subsidies } \\
\text { - Loans and other incentives } \\
\text { - Cost of RETs and components } \\
\text { - Repair and Maintenance service } \\
\text { costs }\end{array}$ \\
\hline $\begin{array}{l}\text { 2. Effective } \\
\text { Management }\end{array}$ & $\begin{array}{l}\text { 2. User Attitude and } \\
\text { Opinion about RET } \\
\text { adoption } \\
\text { - Ownership and } \\
\text { Functioning of RETs } \\
\text { - Presence of Government } \\
\text { Programmes to support } \\
\text { RETs adoption and } \\
\text { continuance } \\
\text { - Reliability } \\
\text { - Success Rating of } \\
\text { Programmes }\end{array}$ & $\begin{array}{l}\text { 2. Functioning and } \\
\text { Usage of RETs }\end{array}$ & $\begin{array}{l}\text { 2. Ease of Operation } \\
\text { - User competence to troubleshoot } \\
\text { faults } \\
\text { - Repair service/AU shops } \\
\text { - Availability of trained technicians } \\
\text { - Response time }\end{array}$ \\
\hline 3. Effective Functioning & & & $\begin{array}{l}\text { 3. Repair and Maintenance } \\
\text { - User competence to troubleshoot } \\
\text { faults } \\
\text { - Repair service/AU shops } \\
\text { - Availability of trained technicians } \\
\text { - Response time }\end{array}$ \\
\hline 4. Financial Viability & & & $\begin{array}{l}\text { 4. Product Design } \\
\text { - Aesthetic appeal } \\
\text { - Recurrence of faults } \\
\text { - Simple and standardized design }\end{array}$ \\
\hline 5. Effective Use & & & $\begin{array}{l}\text { 5. Reliability } \\
\text { - Recurrence of faults } \\
\text { - Utility } \\
\text { - Durability } \\
\text { - Predictable }\end{array}$ \\
\hline 6. Equitable Access & & & 6. Initiation and Sustenance \\
\hline
\end{tabular}




\begin{tabular}{|c|c|}
\hline & $\begin{array}{l}\text { - Awareness generation } \\
\text { - Community participation } \\
\text { - Effective management } \\
\text { - Equitable access } \\
\text { - RETs waste management } \\
\text { - Role of women }\end{array}$ \\
\hline $\begin{array}{l}\text { 7. Participation and } \\
\text { Decision Making }\end{array}$ & \\
\hline $\begin{array}{l}\text { 8. Support for Poverty- } \\
\text { Sensitive and Demand } \\
\text { Responsive } \\
\text { Participation }\end{array}$ & \\
\hline $\begin{array}{l}\text { 9. Expertise of Agencies } \\
\text { Involved }\end{array}$ & \\
\hline
\end{tabular}

RETs Effectiveness Index prepared for the study laid focus on various aspects that had an impact on adoption and sustainability of RETs in rural areas. These were divided into six parameters namely product affordability, ease of operation, repair and maintenance, product design, reliability, and initiation and sustenance. For each parameter and sub- parameters, set of questions were prepared by referring to the existing indices. After discussion with the experts, the questions were finally reduced to a set of twenty-five questions in RETs Effectiveness Index. It was observed during the pilot study and also mentioned by Krishna Kumar (2006) that questions should be kept short and succinct as a lengthy question can confuse respondents and cause them to miss its essential point. Hence, to maintain the reliability of the response the length of the questions was kept short as the questions addressed user opinions, judgments and attitudes towards RET effectiveness.

\subsubsection{Validity of Index}

Keeping in view the research objectives, the index was constructed. After formulating the preliminary index, it was examined for content or rational validity. The standardization was done by consulting the expert in the field of renewable energy, rural extension, home science, statistics and electrical engineering from different organization such as Ministry of New and Renewable Energy, Indian Agricultural and Research Institute (IARI) and Indian Institute of Technology (IIT Delhi), BSES Rajdhani Power Limited and BSES Yamuna Power Limited. The validity of the index for the study was attained through its content validity. Content validity is the extent to which the components within a measurement procedure are relevant and representative of the concept that they will be used to measure (Haynes et al., 1995). Establishing content validity was a necessary initial task in the construction of a new measurement procedure (or revision of an existing one).

The relevant changes were made in the index by reframing several questions after consultation with experts and hence, the final measure of RETs effectiveness was assembled with 25 questions.

\subsubsection{Reliability of Index}

Cronbach's (alpha) was calculated to measure the internal consistency and reliability. In statistics (Classical Test Theory), Cronbach's (alpha) is used as a (lower bound) estimate of the reliability of a psychometric test. It can be viewed as the expected correlation of two tests that measure the same construct. Cronbach's alpha was calculated using the following formula:

$$
\alpha=\frac{K}{K-1}\left(1-\frac{\sum_{i=1}^{K} \sigma_{Y_{i}}^{2}}{\sigma_{X}^{2}}\right)
$$

Where,

$K=$ number of items

$\sigma_{X=\text { variance of the observed total test scores }}^{2}$

$\sigma^{2}$

$\sigma_{Y_{i=}=\text { variance of component } i \text { for the current sample of }}^{2}$ persons.

The index was found to have high degree of internal consistency (Cronbach's alpha: 0.76 for RETs Effectiveness Index, refer Table 3.3) ensuring the reliability of the index. Sattler (2001) has stressed that quotient above 0.7 but below 0.9 is considered relatively reliable while (Nunnaly, 1978) indicated 0.7 as an acceptable reliability coefficient.

Table.3.3: Reliability of RETs Effectiveness Index Developed for the Present Research

\begin{tabular}{|c|c|c|c|}
\hline S.No. & Study Tools & $\begin{array}{c}\text { Reliability } \\
\text { Score }\end{array}$ & $\begin{array}{c}\text { N of } \\
\text { Items }\end{array}$ \\
\hline
\end{tabular}




\begin{tabular}{|c|l|c|c|}
\hline 1 & $\begin{array}{l}\text { RETs } \\
\text { Effectiveness } \\
\text { Index }\end{array}$ & 0.756 & 25 \\
\hline
\end{tabular}

\subsubsection{Scoring of the Index}

Each of the (25) questions in the index were considered as specific indicators of a parameter. Four-point Likert scale was used for the responses ranging from total agreement to total disagreement to the statements. Scores were assigned from 1-4, 1 for the most negative response and 4 for the most positive response. The study was conducted using 4 point Likert scale as it was easier for the rural respondents to understand. In many marketing and intercultural researches, four-point Likert scale has been found to give more reliable results than five-point Likert scale instrument. Multi-dimensional four-point rating scales have been used in many researches to understand the attitude and perception of respondents on items in developed scales.

In a research by Azen and Walker (2011), a 27 item (multi-item) scale used a four-point Likert response mode to an array of items, a sequential use of multiple independent samples was found as an improvement.

Another citing of successful use of four-point Likert scale was found in Cai and Lester (2008), who tested the reliabilities of two versions of the instrument used in their study, with exactly the same items, but one with fourpoint response formats for the Likert scale (that is for each statement, there were four choices: 'strongly agree', 'agree', 'disagree' and 'strongly disagree'), and the other with five-point Likert scales used on a class of 48 (Year 7 students) in China, and it was found that four-point instrument was more reliable (Cronbach alpha 0.72) than five-point instrument (Cronbach alpha 0.59).

For the RETs Effectiveness Index, four items were included in product affordability, ease of operation, repair and maintenance and reliabilityparameter; with a possible score from 4-16. Product designparameter included three items, with a possible range of scores from 3-12 and initiation and sustenanceparameter comprised of six items, with a possible range of scores from 6-24. These items considered the ways in which rural residents assessed the overall effectiveness of RETs.

\subsubsection{Calculation of Effectiveness of RETs Index}

From the scores of six selected parameters of RETs effectiveness index, the overall scores were computed. Therefore, the total possible range of scores for the index was 25-100. The higher the scores for overall RETs effectiveness the more satisfied or optimistic the perceptions of the respondents. The index was translated in Hindi language for interview so that accurate responses could be obtained. The Hindi version had been verified by the experts in Hindi language. After development of index all the parameters were made into a single index for testing the effectiveness RETs on the basis of many parameters. The following formula was used for computation of index score. Index = Summation of Actual Scores of each Subparameters/ Cumulative Maximum Score $x 100$

\subsubsection{Description of Parameters and Sub-parameters of RETs Effectiveness Index}

Effectiveness refers to the degree of correspondence between the actual and the desired outputs of a system. Peter Drucker (1954) pointed out that effectiveness is doing the right things and concentrates on results. To calculate the effectiveness of RETs six parameters comprising various sub-parameters were developed. These included Product Affordability; Ease of Operation; Repair and Maintenance; Product Design; Reliability; and Initiation and Sustenance.

\section{Dimension 1: Product Affordability}

The first parameter refers to the ability of the rural residents to purchase RETs and draw benefit from it in their day-to-day life. A durable product should be affordable to attract more customers to purchase it. Customers often compare the prices on the basis of the features provided such as safety, ease of use, serviceability, quality of parts and products, etc.

1(a) Presence of subsidies: This sub-parameter investigated the importance of subsidies for rural residents to purchase RETs. To make a product attractive to potential users especially in rural areas subsidies were important due to low purchasing power of majority of rural population. Since, RETs were novel in nature and had high initial cost, subsidies became all the more essential.

1(b) Loans and other incentives: MNRE had introduced schemes to provide financial support that was an important additional factor to attract rural consumers towards RET usage. Banks and microfinance organizations offered loans for purchasing RETs. The willingness to purchase product came with the availability of payback time.

1(c) Cost of RETs and components: It focused on the user perception of affordability of RETs on the basis of initial cost of RETs and cost incurred in repair/replacement of BoS components.

1(d) Service cost for repair and maintenance of RETs: Repair and Maintenance service cost of RETs could greatly impact the decision of potential RET customers towards purchasing the product(s).

Dimension 2: Ease of Operation

2(a) Simple functioning: Simple and easy to use products were welcomed by rural residents. Functioning of a device measured the ease with 
which it could be operated by a user without getting a formal training (M.M. Huq, 2003). It also highlighted the usability of the product by the rural users.

2(b) Procure and install: Ease in procurement of RETs was one of the major features to influence their adoption. If a device was easy to procure and install, the number of users to adopt the devices increase by a significant proportion (Wayne D. Hoyer, Deborah J. MacInnis 2008).

2(c) Ease of transportation and storage: Another factor which influenced the adoption of RETs was their ease of storage and transport. Users tend to get devices which were easily portable. This gave them flexibility in terms of usage of the product (Wayne D. Hoyer, Deborah J. MacInnis 2008).

2(d) Availability of components: Over the years of usage, the RETs had been subjected to wear and tear (especially the one placed outdoors). Availability of easy repair of products was important for the users. Availability of spare part was critical for higher acceptability of RETs.

\section{Dimension 3: Repair and Maintenance}

For good customer experience, getting an appointment (from technician) as soon as possible was important, i.e. transparency in approach, reasonable and efficient service window. With tighter margins and a more competitive landscape, efficient customer service could be used to attract new users and retain the existing ones. Not valuing customers' time by delay in scheduling additional visits (if needed to complete the work) was a sure way to let business go to competitors and in case of RETs, a switch back to NRETs or moving down the energy ladder.

3(a) User competence to troubleshoot faults: This sub-parameter explored user ability to troubleshoot problem on their own. As RETs were electronic products, it became easier for rural people to use and maintain them. If troubleshooting them was easy and minor faults could be mend by their own self without assistance of servicing staff, it would increase the adoption of RETs manifolds.

3(b) Presence of repair service /AU shops: Service refers to auxiliary or peripheral activities that were performed to enhance the primary product or primary service. Users were concerned not only about a product breaking down, but also about the elapsed time before service was restored, the timeliness with which service appointments were kept, the nature of their dealings with service personnel and the frequency with which service calls or repairs fail to resolve outstanding problems. Some of these variables could be analyzed quite objectively while others reflected differing personal standards of what constitutes to an acceptable service. For example, a recent study of consumer satisfaction with professional services found the major complaints to be that "the service was provided in a careless, unprofessional manner" and that "I feel I was treated as an object rather than as an individual". Users had different perceptions about the shops meant for repair and maintenance of RETs. Some users felt that Government maintained shops were more reliable as compared to the private shops.

3(c) Availability of trained technicians: In order to execute proper repair and service of the RETs it was imperative to have trained technicians who were skilled to resolve the problems that arise over a period of time. Trained technicians drove the growth of products and increased adoption of the products (Hawkins and Mothersbaugh, 2011).

3(d) Response time: Human factors research attempts to determine human capabilities in areas such as response time and flexibility (Hawkins and Mothersbaugh, 2011). The user expectation of response time was determined by the need of the equipment being used by them, as products vital for daily activities such as solar home lighting system, water heaters required quick response time for installation or repair. Users define response time to be one of the most important factors that impact the adoption of RETs.

\section{Dimension 4: Product Design}

4(a) Aesthetic appeal: Both aesthetics and perceived quality were closely related to the user-based approach. Aesthetics refers to how a product looks, feels, sounds, tastes or smells. It was clearly a matter of personal judgment and reflections of individual preferences.

4(b) Recurrence of faults: It was mostly dependent on the extent of usage and upkeep of the RETs which influenced the wear and tear of the product. These products required repair, hence perception of users about the recurrence of faults varied on the basis of individual usage and knowledge about maintenance. Products installed outdoors relatively had higher requirement of repair.

4(c) Simple and Standardized design: Users in rural areas preferred those RETs which were simple and easy to operate. Products that required skilled operation had lower adoption rate as compared to the ones that could be operated by anyone without assistance.

\section{Dimension 5: Reliability}

Reliability reflected the probability of a product failing or provide service for a specified period of time. To 
understand the reliability of RETs, it was required that a product had been used for some time. This was more relevant w.r.t durable goods than services that were consumed instantly.

Perceptions of quality could be as subjective as assessments of aesthetics since, users did not always possess complete information about the attributes of a product. Hence, as a solution they had to frequently rely on indirect measures such as comparing brands. Also both reputation, i.e., the historical strength of the department and affiliation, i.e., the quality of the university to which a department was attached were equally important in explaining the rankings (Knudsen and Vaughan, 1969). In case of RETs, products purchased from $A U$ shops were reputed for their quality because the shops were affiliated to the Government.

5(a) Supplementing NRETs: One of the key aspects of reliability is resistance to failure. The lesser the probability of failing directly translates to higher reliability (Hawkins and Mothersbaugh, 2011). RETs should be more resistance to failure to increase their perception as reliable products by users.

5(b) Utility: Another important aspect the users look for in a product is utility. The products which help users in their core activities are considered to be of higher utilities than the products which have on and off usage. The lighting products are prime example of this as they help to perform core activities after sundown they are perceived to be of higher utility.

5(c) Durable: Durability is a measure of product life that has both economic and technical dimensions. It can be defined as the extent of usage one gets from a product before it physically deteriorates. A perfect example of this is the light bulb that requires replacement after specific hours of use as the filament burns up and the repair is impossible. Economists call such products 'one-hoss shays' and had used them extensively in modeling the production and consumption of capital goods (Bliss, 1975).

Durability becomes difficult to interpret when repair is possible as the concept takes on an added dimension, for the life of product will vary with the change in economic conditions. Durability becomes the amount of use one gets from a product before it breaks down and replacement was preferable to continued repair. The product-based approach focused on performance, features and durability of RETs along with the manufacturing-based approach focused on conformance to standards. MNRE had tried to take care of all these factors to ensure the durability of RETs by establishment of $A U$ shops and introducing minimum specification for standardization of RETs and establishment of test centers to certify the same.

5(d) Predictable: This sub-parameter catered to find out the predictability of RETs as perceived by rural residents. Consumers purchased products for the ease and comfort they brought to the life. The predictability or the presence of service brought satisfaction and assured the use of RETs for longer duration.

Dimension 6: Initiation and Sustenance

6(a) Awareness generation: This sub-parameter focused on the association of awareness of RETs such as long-term benefits, cost-effectiveness, fuelsaving, presence of financial support, subsidies, etc. with increase in willingness of rural residents to purchase and use RETs.

6(b) Community participation: A community can derive considerable benefits from becoming involved in the developments and operation of energy projects in rural areas. This sub-parameter investigated the community involvement in renewable energy programmes. Despite their contribution to sustainability, the perception varied as few believed that the involvement of residents (potential users/beneficiaries) was sought by developers only when permission or space was required for installation. Community needs were not paid much attention and focus was just on achieving physical targets of the schemes. Hence, such schemes were considered as unwelcomed intrusion from the outsiders, exploiting natural resources and offering little in return to the community.

6(c) Effective management: In order to establish and make a renewable energy project successful, a well-planned strategy and management must be acquired. It was an important attribute for longterm sustenance of the RETs (Acharya and Aithal, 2015). The key parameters to ensure effective management were knowledge of product and userfriendly operation.

6(d) Equitable access: In order to increase the adoption of RETs in rural areas, it was imperative to ensure that all the residents had equitable access to products (to benefit from them) and also to repair and maintenance services (nearby their $\mathrm{HH}$ or community) to ensure that the products were used to their full potential.

6(e) RETs waste management: The main differentiator of RETs from NRETs was the proenvironment nature of the equipment. Residents 
believed in adopting RETs for they had positive impact on their lifestyle without causing harm to the environment. Though there were many bottlenecks in management of waste generated from RETs that required attention.

6(f) Role of women: RETs played direct role in improving the lifestyle of women in rural areas. Women were responsible for various $\mathrm{HH}$ activities such as cooking, cleaning and outdoor HH work which were vastly influenced by adoption of RETs (Remedios and Rao, 2013).

\subsection{Change in Quality of Life (QoL) Index w.r.t RET Usage}

\subsubsection{Rationale for Development of Index}

The QoL index was developed for the following reasons-

(a) During the review, various existing QoL indices were explored, most of which were relevant for elderly such as were disease specific, focused on psychological and spiritual well- being and so on. For the purpose of the study it was pertinent to device a scale that could measure impact of RETs on QoL of users. Therefore, the domains had to focus on the impact of RET usage on QoL of rural residents w.r.t education, health, income-generation, safety and security, comfort and convenience (refer Table 3.4).

(b) The present research focused on exploring the change in QoL of RET users in selected rural areas. Since, the residents had been using RETs from the past many years their perception was primarily based on experience on account of using RETs using recall method.

\subsubsection{Method of Development of Index}

Development of Change in QoL Index was executed in the following stages:

- Concept clarification involved review of literature and consultation of experts to finalize the various dimensions to study the change in quality of life of rural residents w.r.t RET usage.

- Review of existing indices on change in QoL and determine the relevant dimensions to develop an index for the present research.

- Review of the proposed QoL index and check its reliability and validity.

Table.3.4: Change in QoL Index Developed for the Present Research

\begin{tabular}{|c|c|c|}
\hline S.No. & Quality of Life Parameters & Sub-Parameters \\
\hline 1 & Education of Children & $\begin{array}{l}\text { - Increased study time at home } \\
\text { - Improved academic performance } \\
\text { - Regularity to school/college } \\
\text { - Participation in co-curriculum activities } \\
\text { - Access to education services/utilities outside home }\end{array}$ \\
\hline 2 & Healthcare & $\begin{array}{l}\text { - Better access for elderly } \\
\text { - Better access for women and children } \\
\text { - Improved availability of medical facilities/service } \\
\text { - Decreased indoor pollution } \\
\text { - Better healthcare at home } \\
\end{array}$ \\
\hline 3 & Convenience and Social Life & $\begin{array}{l}\text { - Increased leisure time } \\
\text { - Ease in conducting HH activities } \\
\text { - Improved social life } \\
\text { - Better family relationships } \\
\text { - Living an active life }\end{array}$ \\
\hline 4 & Safety and Security & $\begin{array}{l}\text { - Decrease in incidences of theft } \\
\text { - Safety from wild/stray animals } \\
\text { - Decrease in accidents } \\
\text { - Safety inside home } \\
\text { - Sense of security }\end{array}$ \\
\hline 5 & $\begin{array}{lll}\text { Income Generation } & \text { and } \\
\text { Financial Security } & \end{array}$ & $\begin{array}{l}\text { - New-start ups } \\
\text { - Ease in conducting existing work } \\
\text { - Better time management } \\
\text { - Regularity to work place } \\
\text { - Increased productivity/profitability }\end{array}$ \\
\hline
\end{tabular}




\begin{tabular}{|l|l|}
\hline Validity of Index & The validity of the index was attained through Content Validity. \\
\hline Reliability of Index & $\begin{array}{l}\text { Cronbach's (alpha) was calculated to measure the internal } \\
\text { consistency and reliability. The index had high degree of internal } \\
\text { consistency (Cronbach's alpha: 0.84). }\end{array}$ \\
\hline
\end{tabular}

\subsubsection{Selection of Dimensions for Change in QoL Index}

Amongst the QoL indices studied, following four indices seemed relevant in the context of present study. An indepth analysis of different dimensions covered in selected change in QoL index was done and relevant dimensions were selected for the study (refer Table 3.5).

(a) PV System Acceptance Test(2000): QoL Score cards were developed by New Mexico State University's Southwest Technology Institute and Winrock International. This test was comprehensive in nature as it comprised of questions pertaining to the assessment of effectiveness of PV electrification by the rural residents as well as the change felt by them in their lives with its usage. The test comprised of score cards and focused on grid-connected system only.

(b) WHO QoL Scale, Extended Version (1991): This version has been prepared by QoL Group, World Health Organization (WHO). The dimensions in this scale primarily focused on individual perception of inter-personal relationships as well as personal wellbeing in terms of level of independence, economic, health and psychological well-being.

(c) QoL: A System's Model(2001): The University of Oklahama School of Social Work prepared this model. The approach to the measurement of the quality of life derived from the position that there were a number of domains of living. Each domain contributed to one's overall assessment of the quality of life. The domains include in this model were family and friends, work, neighborhood (shelter), community, health, education and spirituality. All of these domains were included in the developed index for the present research in the context of user perception of change in their quality of life as a result of RET usage (refer Figure 3.1).

(d) QoL Index- Ferrans and Powers (1984): Ferrans and Powers prepared this index. It comprised of thirty-three items on four domains, i.e., social and economic, psychological, health and functioning, spiritual and family. The subjects attributed scores on scales designed for satisfaction and importance with values ranging from 1 to 6 . Hence, the responses were analyzed using qualitative methodology. These domains were included in the developed QoL index for the present research with a prime focus on satisfaction (significant change) or no satisfaction (no change) experienced by the rural residents w.r.t RET usage.

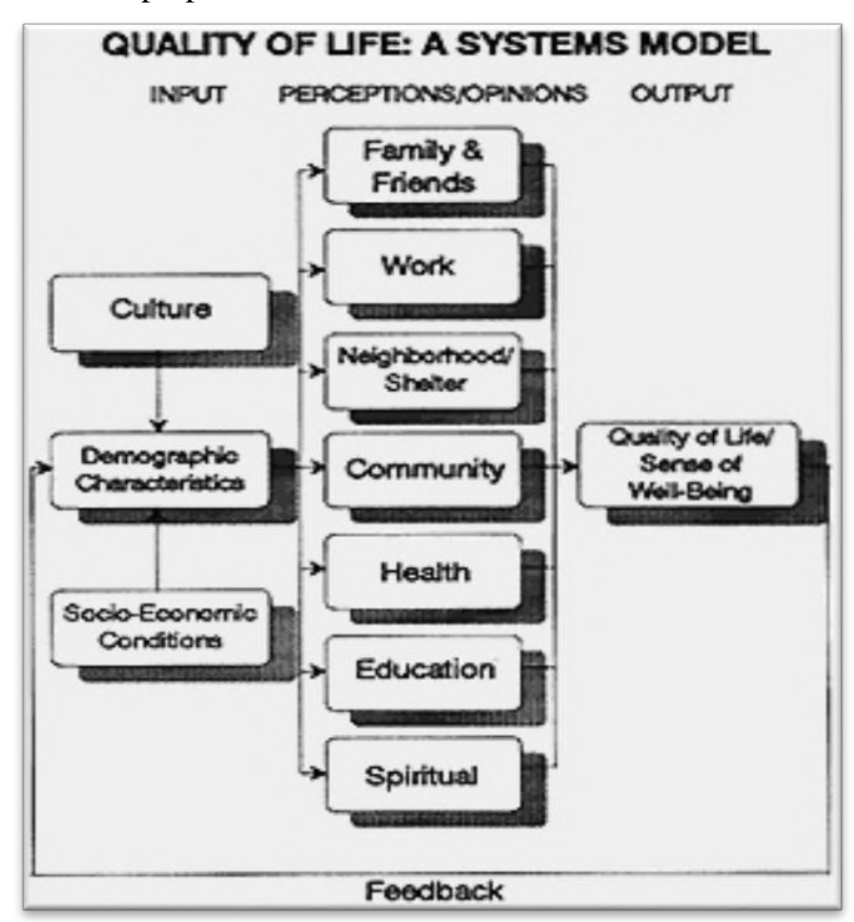

Fig.3.1: Quality of Life: A Systems Model by University of Oklahama School of Social Work (2001) 
For each dimension and sub-dimension, set of questions were prepared by referring to the existing indices. After discussion with the experts, the questions were finally reduced to a set of 25 questions in 'Change in QoL Index'. To maintain the reliability of the response the length of the questions was kept short as the questions addressed user opinions, judgments and attitudes of RET users towards their QoL. The index comprised of five dimensions, namely, education of children; healthcare; convenience and social life; safety and security; and income generation and financial security (refer Table $3.5)$.

Table.3.5: Dimensions of QoL Index Covered in Other Researches and Developed for the Present Research

\begin{tabular}{|c|c|c|c|c|}
\hline $\begin{array}{l}\text { PV System Acceptance } \\
\text { Test (2000): Score cards } \\
\text { developed by New } \\
\text { Mexico State University } \\
\text { and Winrock } \\
\text { International }\end{array}$ & $\begin{array}{l}\text { WHO QoL Scale: } \\
\text { Extended Version } \\
\text { (1991) by QoL Group } \\
\text { WHO }\end{array}$ & $\begin{array}{l}\text { QoL: A System's } \\
\text { Model (2001) by } \\
\text { The University of } \\
\text { Oklahama School of } \\
\text { Social Work }\end{array}$ & $\begin{array}{l}\text { QoL Index- } \\
\text { Ferrans and } \\
\text { Powers } \\
(\text { 1984) by } \\
\text { Ferrans and } \\
\text { Powers } \\
\end{array}$ & $\begin{array}{l}\text { Change in QoL } \\
\text { dimensions for the present } \\
\text { study }\end{array}$ \\
\hline 1. Education & $\begin{array}{l}\text { 1.Physical } \\
\text { - Energy and fatigue } \\
\text { - Sleep and rest } \\
\text { - Pain and discomfort }\end{array}$ & $\begin{array}{l}\text { 1. Culture } \\
\text { - Work } \\
\text { - Neighborhood } \\
\text { - Family } \\
\text { - Friends }\end{array}$ & $\begin{array}{l}\text { Health and } \\
\text { Functioning }\end{array}$ & $\begin{array}{l}\text { 1. Education of Children } \\
\text { - Increased study time at } \\
\text { home } \\
\text { - Improved academic } \\
\text { performance } \\
\text { - Regularity to school// } \\
\text { college } \\
\text { - Participation in co- } \\
\text { curriculum activities } \\
\text { - Access to education } \\
\text { services/ utilities outside } \\
\text { home }\end{array}$ \\
\hline $\begin{array}{l}\text { 2. Income-Generation } \\
\text { Activities }\end{array}$ & $\begin{array}{l}\text { 2. Psychological } \\
\text { - Positive feeling } \\
\text { - Thinking, memory and } \\
\text { concentration } \\
\text { - Self-esteem }\end{array}$ & $\begin{array}{l}\text { 2. Demographic } \\
\text { Characteristics } \\
\text { - Community } \\
\text { - Health }\end{array}$ & $\begin{array}{l}\text { Social } \\
\text { - Family }\end{array}$ & $\begin{array}{l}\text { 2. Healthcare } \\
\text { - Better access for elderly } \\
\text { - Better access for women } \\
\text { and children } \\
\text { - Improved availability of } \\
\text { medical facilities/service } \\
\text { - Decreased indoor pollution } \\
\text { - Better healthcare at home }\end{array}$ \\
\hline 3. Domestic Productivity & $\begin{array}{l}\text { 3. Social Relationships } \\
\text { - Personal relationships } \\
\text { - Social support } \\
\text { - Sexual activity }\end{array}$ & $\begin{array}{l}\text { 3. Socio-Economic } \\
\text { Conditions } \\
\text { - Education }\end{array}$ & Spiritual & $\begin{array}{l}\text { 3. Convenience and Social } \\
\text { Life } \\
\text { - Increased leisure time } \\
\text { - Ease in conducting HH } \\
\text { activities } \\
\text { - Improved social life } \\
\text { - Better family } \\
\text { relationships } \\
\text { - Living an active life }\end{array}$ \\
\hline $\begin{array}{l}\text { 4. Information and } \\
\text { Communication }\end{array}$ & $\begin{array}{l}\text { 4. Environment } \\
\text { - Physical safety and } \\
\text { security } \\
\text { - Home environment } \\
\text { - Financial resources } \\
\text { - Health and social care } \\
\text { - Physical environment } \\
\text { and transport }\end{array}$ & 4.Spiritual & & $\begin{array}{l}\text { 4. Safety and Security } \\
\text { - Decrease in incidences of } \\
\text { theft } \\
\text { - Safety from wild/stray } \\
\text { animals } \\
\text { - Decrease in accidents } \\
\text { - Safety inside home } \\
\text { - Sense of security }\end{array}$ \\
\hline
\end{tabular}




\begin{tabular}{|c|c|c|c|c|}
\hline $\begin{array}{l}\text { PV System Acceptance } \\
\text { Test (2000): Score cards } \\
\text { developed by New } \\
\text { Mexico State University } \\
\text { and Winrock } \\
\text { International }\end{array}$ & $\begin{array}{l}\text { WHO QoL Scale: } \\
\text { Extended Version } \\
\text { (1991) by QoL Group } \\
\text { WHO }\end{array}$ & $\begin{array}{l}\text { QoL: A System's } \\
\text { Model (2001) by } \\
\text { The University of } \\
\text { Oklahama School of } \\
\text { Social Work }\end{array}$ & $\begin{array}{l}\text { QoL Index- } \\
\text { Ferrans and } \\
\text { Powers } \\
(1984) \text { by } \\
\text { Ferrans and } \\
\text { Powers }\end{array}$ & $\begin{array}{l}\text { Change in QoL } \\
\text { dimensions for the present } \\
\text { study }\end{array}$ \\
\hline 5. Convenience/ Comfort & 5.Spirituality/ Personal & & & $\begin{array}{l}\text { 5. Income Generation and } \\
\text { Financial Security } \\
\text { - New-start ups } \\
\text { - Ease in conducting } \\
\text { existing work } \\
\text { - Better time management } \\
\text { - Regularity to work place } \\
\text { - Increased productivity/ } \\
\text { profitability }\end{array}$ \\
\hline 6. Health care and Safety & $\begin{array}{l}\text { 6. Level of } \\
\text { Independence } \\
\text { - Mobility } \\
\text { - Activities of daily } \\
\text { living } \\
\text { - Dependence on } \\
\text { medication or } \\
\text { treatment } \\
\text { - Work capacity }\end{array}$ & & & \\
\hline
\end{tabular}

\subsubsection{Validity of Index}

The validity of the QoL index was attained through the content validity. Keeping in view the research objectives the indices were constructed. After formulating the preliminary QoL index, it was examined for content or rational validity. The standardization was done by consulting the expert in the field of renewable energy, rural extension, home science, statistics and electrical engineering from different organization such as Ministry of New and Renewable Energy, Indian Agricultural and Research Institute (IARI) and Indian Institute of Technology (IIT Delhi), BSES Rajdhani Power Limited and BSES Yamuna Power Limited. The relevant changes were made in the index by reframing several questions after consultation with experts. Hence, the final measure of QoL was assembled with twenty-five questions.

\subsubsection{Reliability of Index}

Cronbach's (alpha) was calculated to measure the internal consistency and reliability. The indices were found to have high degree of internal consistency (Cronbach's alpha: 0.84 for QoL Index, refer table 3.6) ensuring the reliability of the index.

Table.3.6: Reliability of Change in QoL of Residents Index w.r.t RETs Usage Developed for the Present Research

\begin{tabular}{|r|l|c|c|}
\hline S.No. & $\begin{array}{l}\text { Study } \\
\text { Tools }\end{array}$ & $\begin{array}{c}\text { Reliability } \\
\text { Score }\end{array}$ & $\begin{array}{c}\text { N of } \\
\text { Items }\end{array}$ \\
\hline 1 & $\begin{array}{l}\text { Quality } \\
\text { of Life } \\
\text { Score } \\
\text { Cards }\end{array}$ & 0.835 & 25 \\
\end{tabular}

\subsubsection{Scoring of Index}

Each of the (25) questions in the index were considered as specific indicators of a dimension. Four-point Likert scale was used for the responses ranging from total agreement to total disagreement to the statements. Scores were assigned from 1-4, 1 for the most negative response and 4 for the most positive response. The study was conducted using 4 point Likert scale as it was easier for the rural respondents to understand.

In the QoL Index, five dimensions were included 'education of children'; 'healthcare'; 'convenience and social life'; 'safety and security'; and 'income generation and financial security'; with a possible score from 5-25. The QoL index included dimensions and sub-dimensions that considered the ways in which rural residents assessed the overall change in their QoL w.r.t RET usage.

\subsubsection{Calculation of Change in QoL Index}

From the scores of five dimensions of QoL index, the overall scores were computed. Therefore, the total 
possible range of scores for the index was 25-100. The higher the scores for overall change in QoL, the more satisfied or optimistic the perception of the respondents. The index was translated in Hindi language for interview so that accurate responses could be obtained. The Hindi version had been verified by the experts in Hindi language. The following formula was used for computation of index score.

Index $=$ Summation of Actual Scores of Each Subdimensions/cumulative maximum score $x 100$

\subsubsection{Description of Dimensions and Sub-Dimensions of Change in QoL Index}

Quality of life (QOL) has been defined by Ferrans (1990) as "a person's sense of well-being that stems from satisfaction and dissatisfaction with the areas of life that are important to him or her". The index was constructed to understand the user's perception of change in their quality of life with the use of RETs. There were 5 dimensions to determine change in the quality of life of users. These are discussed as follows:

\section{Dimension 1: Education of Children}

Change in education forms the basis of many renewable energy programs. This dimension investigated the changes witnessed by the residents of selected villages w.r.t change in home study time, academic performance, regularity to school, participation in co-curricular activities and access to educational facilities outside home.

1(a) Increased study time at home: Awareness for importance of education was increasing in rural areas hence, many families emphasized on education of their children. In many villages where electrification from conventional (electric) grid was either not present or the power supply was erratic, residents considered RETs as an alternative solution.

1(b) Improved academic performance: This subdimension was a result of various other developmental activities in the village. The perception of users about the influence of RETs usage on improving their child's academic scores was of importance for understanding the change in education with use of RETs.

1(c) Regularity to school/college: This sub-dimension was critical to understand the impact of RETs on regularity of children to school. For instance, hot water was required in the morning to take bath hence, solar water heaters provided convenience and were available even if power supply was not available, preventing any delay in reaching school on time. 1(d) Participation in co-curricular activities: $\mathrm{Co}-$ curricular activities formed a winning part of complete education. It provided opportunities for character development and valuable life lessons such as teamwork, sportsmanship, self-discipline and hard work. This helped students to become responsible adults, productive citizens and skilled professionals. This sub-dimension attempted to find out improvement in participation of children in co-curricular activities with the use of RETs.

1(e) Access to education services/utilities outside home: Many Government health centers were not able to operate after sundown. This sub-dimension measured the effect of RET usage on the functioning of utilities and education services. On adoption of RETs there was a possibility to keep utility services open even after sunset.

\section{Dimension 2: Healthcare}

Improvement in rural health service was important as the availability of electricity to support proper services such as provision of vaccines, medicines, healthcare professionals etc. was inadequate. An appropriate RET could help in expanding the opportunities for better healthcare available within or near the rural communities for residents.

2(a) Better access for elderly: Performing regular functions was difficult for elders in the rural areas where power supply was erratic and of poor quality. However, the adoption of RETs could provide them better access to various healthcare services.

2(b) Better access for women and children: Women and children had higher need of healthcare services in rural areas. RET adoption by the local healthcare institutions could provide better access to healthcare services to women and children.

2(c) Improved availability of medical facilities/service: This sub-dimension was directly related to the operational hours of local healthcare institutions. Adoption of RETs could provide flexibility to run them. This certainly resulted in the improved availability of medical facilities and availability of medical practitioners in rural areas.

2(d) Decreased indoor pollution: This sub-dimension focused on the importance of healthcare needs as it directly affected the health of women who cook using NRETs such as biomass/fuelwood. Adoption of RETs had a positive effect on the pollution levels in the house.

2(e) Better healthcare at home: Healthcare at home could be improved with the usage of RETs that played a significant role in ensuring the proper access to the medical facilities at home.

Dimension 3: Convenience and Social Life 
3(a) Increased leisure time: This sub-dimension was a key attribute to determine comfort and convenience. Usage of RETs provided additional time for leisure activities. The length of the workable day increased with the use of RETs such as solar home lights, solar street lights, solar water heaters, etc.

3(b) Ease in conducting household activities: RETs also provided convenience for conducting $\mathrm{HH}$ activities such as cooking, lighting, water heating, cleaning, etc. This dimensions focused upon the impact on RET usage on the ease and comfort in conducting $\mathrm{HH}$ activities.

3(c) Living an active life: Availability of more spare time resulting from RET usage could be used for socializing with friends, family, relatives and neighbors. Organizing late evening meetings under a tree was possible due to RET usage.

3(d) Better family relationships: Families could spend additional time together as many $\mathrm{HH}$ activities could be performed through a span of day and night therefore, the burden was not felt by women to finish all the chores within a short span of time (i.e, before sunset), that left no scope for rest, leisure, socialize or spend time with near and dear ones.

3(e) Improved social life: Since many public services such as schools and nursing homes were also adopting RETs, the access to facilities were enhanced.

\section{Dimension 4: Safety and Security}

This dimension focused on the perception of rural residents about change in safety and security with the use of RETs. Solar PV technology played a prime role in rural areas. Solar-powered lighting meant that children were able to go out and play after sunset, women felt safe venturing out at late evenings for $\mathrm{HH}$ shopping, temple or evening walks etc. Also, enhancing the feeling of safety among rural HHs from theft, wild animals, etc.

4(a) Decrease in incidence of theft: This subdimension was important to understand the user perception on decrease in theft as an impact of RET usage.

4(b) Safety from wild/stray animals: As revealed in the preliminary discussion with the villagers that the attack from wild animals was common since, the lanes and by-lanes were usually dark due to absence of street lighting. This sub-dimension focused on changes in safety from wild animals with presence of SPV based street lights.

4(c) Decrease in accidents: The incidence of accidents due to low visibility in rural areas was a problem. The introduction of RETs had been a boon to ensure safety from accidents especially in hilly terrain. The user perception of change in such incidences was found in this sub-dimension.

4(d) Safety inside home: The safety inside the home referred to the safety from mishaps (falling or hurting due to lack of visibility) at home especially for children, sick, elderly and pregnant women.

4(e) Sense of security: A positive feeling of safety and security with the use of RETs.

Dimension 5: Income Generation and Financial Security

For a renewable energy project to bring about considerable benefits to rural communities by way of enhancing the profitability and productivity of existing income-generation activities as well as assist in new startups. The resultant increase in income would help in better sustenance and adoption of RETs.

5(a) New start-up: This sub-dimension investigated the impact of RETs in the lives of rural people w.r.t taking up new work to enhance their existing $\mathrm{HH}$ income.

5(b) Ability and ease in conducting existing work: This sub-dimension referred to the user perception of change in their ability to conduct existing work with ease and comfort as a result of RET usage.

5(c) Better time management:Planning and exercising control over the amount of time spend on specific activities, especially to increase effectiveness, efficiency or productivity was important. The aim of this sub-dimension was whether rural residents were able to identify the impact of RETs in helping one exercise such control so that efficiency to conduct existing work and ability to take up new was increased.

5(d) Regularity to work place: To understand the contribution of RETs towards regularity of users to their respective work place was the aim of this subdimension.

5(e) Increased productivity/ profitability: A potential benefit of implementing sustainable energy options included strategies to improve rural conditions by linking RETs with productive uses. Most of the renewable energy projects implemented so far in the rural areas had concentrated on residential or $\mathrm{HH}$ applications. The use of renewable energy to increase productivity and profitability can help in sustenance and adoption of RETs in rural areas.

\section{ACKNOWLEDGMENT}

This research was supported by Ministry of New and Renewable Energy. We are thankful to Dr. LeninVenu who provided expertise that greatly assisted the research and we also express our appreciation to our colleague Dr. 
Mayanka Gupta for sharing her pearl of wisdom with us during the course of this research for development and administration of rating scales to access effectiveness of RETs and change in quality of life of residents with respect to RETs usage. We are immensely grateful to them for their comments on an early version of the manuscripts, although they may not agree to the interpretations provided in this paper.

\section{REFERENCES}

[1] Acharya, S.P. and Aithal, S.P. (2015). Innovations in Effective Management of Energy Using Green Technology. International Journal of Conceptions on Management and Social Sciences. Vol.3, Issue 2, April 2015; ISSN: 2357-2787.

[2] Azen, R. and Walker, C.M. (2011). Categorical Data Analysis for the Behavioral and Social Sciences, New York: Taylor and Francis.

[3] Barnes, F.D. and Floor, M.W. (1996). Rural Energy in Developing Countries: A Challenge for Economic Development. Annual Review of Energy and the Environment. Power Development, Efficiency and Household Fuels Division, Industry and Energy Department, The World Bank. Vol. 21: 497-530.

[4] Balachandra, P. (2011). Energy Poverty: Global Challenges and Local Solutions, Oxford University Press. pp 237-247.

[5] Balachandra, P. (2011) 'Dynamics of Rural Energy Access in India: An Assessment'. Energy, 36(9). pp 5556-67.

[6] Bliss, C. J. (1975). Capital Theory and the Distribution of Income. Amsterdam: North-Holland.

[7] Cai, J. and Lester, F. (2008). Contributions from Cross-National Comparative Studies to the Internationalisation and Globalisation in Mathematics and Science Education. Springer Science and Business Media B.V. pp 269-283.

[8] Census of India (2001). Tables on houses, household amenities and assets. Retrieved from http://www.censusindia.net/2001housing/housing_ta bles_main.html, assessed on October 4, 2011.

[9] Census of India (2011). Census of India Dashboard. Retrieved from Census of India:http://www.censusindia.gov.in/2011census/PC A/PCA_Highlights/pca_highlights_india.html accessed on August 24, 2013,

[10] Census of India (2011a). Census of India Dashboard. Retrieved from Devinfolive:http://www.devinfolive.info/censusinfo dashboard/website/index.php/pages/kitchen_fueluse d/total/Households on August 27, 2013.
[11]Chaurey, A, Ranganathan, M. and Mhanty, P. (2004). Electricity Access for Geographically Disadvantaged Rural Communities- Technology and Policy Insights. Energy Policy. pp 1693-1705.

[12]Drucker, Peter F. (1954). The Practice of Management. Harper and Brothers. New York.

[13]Ferrans, C. E. (1990). Development of a Quality of Life Index for Patients with Cancer. Oncology Nursing Forum, 17(3). pp15-19.

[14] Gupta, M (2014). 'Quality of Life of Elderly in Old Age Homes and Recreation Centres'. Lady Irwin College, Delhi University, Delhi.

[15] Goel, S. (2005). 'Ergonomics of Lighting for Reading'. Lady Irwin College, Delhi University, Delhi.

[16] Hawkins, D.I. and Mothersbaugh, D.L. (2011). Consumer Behavior, Building Marketing Strategy, Mc Graw Hill, Eleventh Edition.

[17] Hoyer, W.D. and MacInnis, D.J. (2008). Consumer Behaviour, Fifth Edition.

[18] International Energy Agency (IEA), 2008. World Energy Outlook. Review of international policies for vehicle fuel efficiency, OECD/IEA, Paris. Retrieved from

http://www.worldenergyoutlook.org/media/weowebs ite/2008-1994/ weo2008.pdf accessed on 27 November, 2015.

[19] International Energy Agency (IEA), 2009. World Energy Outlook 2009, OECD/IEA, Paris. Retrieved from

http://www.worldenergyoutlook.org/media/weowebs ite/ 2009/WEO2009.pdf accessed on August 24, 2015.

[20] International Energy Agency (IEA), 2015. World Energy Outlook. Energy and Climate Change. Retrieved from https://www.iea.org/publications/ publication/WEO2015SpecialReportonEnergyandCl imateChange.pdf accessed on August 22, 2015.

[21] International Energy Agency (IEA), 2015. World Energy Outlook. 'Modern energy for all: why it matters?'. Retrieved from Www.worlenergyoutlook.org accessed on August 14, 2015.

[22] International Energy Agency (IEA), 2014. World Energy Outlook 2014 Factsheet. How will Global Energy Market Evolve to 2040? Retrieved from http://www.worldenergyoutlook.org/media/weowebs ite/2014/141112_weo_factsheets.pdf_accessed on August 12, 2015.

[23] India Core (2015). The Online Resource for Information on the Indian Infrastructure and Core Sectors. Retrieved from 
www.indiacore.comaccessed on November 23, 2015.

[24] Jangu, S.L. (2015), 'Challenges of Development in North East India: A Socio-Ecological Perspective'. Environmental Conservation and Sustainable Development, Indira Gandhi centre for Human Ecology, Environmental and Population Studies, University of Rajasthan, Lenin Media, Delhi. pp. 167-183.

[25] Kumar, A., Kumar, K., Kaushik, N., Sharma, S. and Mishra, S. (2010). Renewable energy in India: Current Status and Future Potentials. Renewable and Sustainable Energy Review, Vol 14. Science Direct. pp 2434-2442.

[26] Knudsen, D.D. and Vaughan, T. R. (1969). 'Quality in Graduate Education: A Re-evaluation of the Rankings of Sociology Departments in the Cartter Report'. American Sociologist. pp. 18.

[27] Kumar, A. and Kandpal, T.C. (2007). Renewable Energy Technologies for Irrigation, Water Pumping in India: A Preliminary Attempt Towards Potential Estimation. Energy 32(5). pp 861-870.

[28] Kumar, A. and Mathur, R. (2009). Role of Renewable Energy in India. Yojana. pp 28-31.

[29] Kumar, U. (2012). A study of Rural Electrification in India- Challenges and Alternatives. JJT University. Renewable Energy Journal ISSN 23211067. pp 9-20.

[30] Mahapatra, S. and Dasappa, S. (2012). Rural electrification: optimizing the choice between decentralized renewable energy sources and grid extension. Energy for Sustainable Development (16). pp. 146-154

[31] Martinot, E. (2005). Renewable Report Global Status Report. Paris: Renewable Energy Policy Network for the $21^{\text {st }}$ century.

[32] Mathur, M. and Goswami, S. (2015), 'Analyzing Perception of Millennium towards Sustainable Consumption'. Environmental Conservation and Sustainable Development, Indira Gandhi centre for Human Ecology, Environmental and Population Studies, University of Rajasthan, Lenin Media, Delhi. pp. 47-54.

[33] MERC (2013). Maharashtra Electricity Regulatory Commission (MERC). Retrieved from http://www.mercindia.org.in/pdf/Order\%2058\%204 2/Order_Case $\% 20$ No\%2049\%20of\%202013$22 \% 20 \mathrm{July} \% 202013$.pdf accessed on October 4, 2014.

[34] Ministry of New and Renewable Energy (MNRE), 2012. Off-grid schemes for Remote Village Electrification. Retrieved from http://mnre.gov.in/schemes/ offgrid/remote-villageelectrification accessed on May 4, 2012.

[35] Ministry of New and Renewable Energy (MNRE), 2012. Solar Thermal and Photovoltaic Field Engineers Training Course, New Delhi by MNRE. Retrieved from http://mnre.gov.in/filemanager/UserFiles/Solar-thermal-and-photovoltaicfield-engineer-training-course.pdf accessed on August 8, 2014.

[36] Ministry of New and Renewable Energy (MNRE), 2015. Solar Parks and Ultra Mega Solar Power Projects Scheme. Retrieved from http://mnre.gov.in/file-manager/UserFiles/DraftScheme-Solar-Park-and-Ultra-Mega-Solar-PowerProjects-for-comments.pdf accessed on January 12, 2016.

[37] Ministry of Power (MoP), 2003. Discussion Paper on Rural Electrification Policies. Government of India, New Delhi. Retrieved from http://powermin.nic.in/ Rural-Electrification accessed on August 27, 2013.

[38] Ministry of Power (MoP), 2005. Rajiv Gandhi Grameen Vidhyutikaran Yojna. Government of India, New Delhi. Retrieved from http://powermin.nic.in/ initiatives accessed on August 27, 2013.

[39]Huq, M.M. (2003). Building Technological Capability: Issues and Prospects, Nepal, Bangladesh and India. University Press. pp.15-80.

[40]Ministry of Statistical and Programme Implementation (MoSPI), 2011. Energy Statistics 2011. Retrieved from http://mospi.nic.in/Mospi_New/upload/ energy_stat_2011_pdf/table_section_2_es10.pdf accessed on 12 October 2014.

[41] Ministry of Power (MoP), 2012. India Electricity Scenario 2012. Retrieved from http://powermin.nic.in/upload/pdf/Annual_Report_2 012-13_English.pdf accessed on 12 October 2014.

[42] National Sample Survey Office (NSSO), 2001. Level and Pattern of Consumer Expenditure, 19992000. New Delhi: Ministry of Statistics and Programme Implementation (MoSPI), Government of India.

[43] National Sample Survey Office (NSSO), 2006. Level and Pattern of Consumer Expenditure, 200405. New Delhi: Ministry of Statistics and Programme Implementation (MoSPI), Government of India.

[44] National Sample Survey Office (NSSO), 2011. Level and Pattern of Consumer Expenditure, 200910. New Delhi: Ministry of Statistics and 
Programme Implementation (MoSPI), Government of India.

[45] National Sample Survey Office (NSSO), 2012. Energy Sources of Indian Households for Cooking and Lighting, 2010-2011. New Delhi: Ministry of Statistics and Programme Implementation (MoSPI), Government of India.

[46] Painuly, J.P. (2001). Barrier to renewable energy penetration; a framework for analysis. Renewable Energy 24. pp 73-89.

[47] Painuly, J.P. and Fenhann, J.V. (2002). Implementation of Renewable Energy Technologies - Opportunities and Barriers. Summary of Country Studies. UNEP Collaborating Centre on Energy and Environment, RIS $\varnothing$ National Laboratory, Roskilde, Denmark.

[48] Pawar, V. and Kaur, T. (2014). Overview of Renewable energy resources of India. International Journal of Advanced Research in Electrical, Electronic and Instrumentation Engineering, 3 (2), ISSN 2278-8875. pp 7118-7119.

[49] Planning Commission (2012). Eleventh Five Year Plan of the Government of India. In P. Commission (Ed.) New Delhi: Planning Commission. Vol. 3. pp.383-385.

[50] Planning Commission (2013). Press Note on Poverty Estimates, 2011-12. Retrieved from Planning Commission:

http://planningcommission.nic.in/news/pre_pov2307.p df accessed on August 24, 2013.

[51] Remedios, L. and Rao, S. (2013). Rethinking Education: The Solar Initiative. Barefoot College, Tilonia, Rajasthan. Retrieved from http://www.undp.org/content/ dam/india/docs/human development/BAREFOOT_COLLEGE_INDIA_ PRESENTATION.pdf accessed on January 7, 2015.

[52] Renewable Energy Regulatory Framework (2012). Retrieved from http://mnre.gov.in: http://mnre.gov.in/information/renewable-energyregulatory framework accessed on October 4, 2014.

[53] Renewable Energy Regulatory Framework (2013). Retrieved from http://mnre.gov.in: http://mnre.gov.in/mission-and-vision-

2/achievements/accessed on October 4, 2014.

[54] Renewable Energy Regulatory Framework (2015). Retrieved from http://mnre.gov.in: http://mnre.gov.in/mission-and-vision-

2/achievements/accessed on January 5, 2016.

[55] The Energy and Resource Institute (TERI), 2001. Poverty reduction through energy projects. The Energy and Research Institute Project Report No.2000RD41. pp 111.
[56] The Energy and Resource Institute (TERI), 2007. Domestic Energy Demand, TERI Energy Data Directory and Yearbook (TEDDY). The Energy and Resource Institute, Teri Press, ISBN 81-7993-162-5. pp 525-526.

[57] The Energy and Resource Institute (TERI), 2013. Domestic Energy Demand, TERI Energy Data Directory and Yearbook (TEDDY). The Energy and Resource Institute, Teri Press. pp 326-328.

[58] Tiwari, G. and Mishra, R. (2012). Advanced Renewable Energy Sources. Cambridge: RSC Publishing.

[59] Varma, P. (2012). Renewable energy in IndiaBusiness opportunities. Retrieved from cci.gov.in on December 4, 2012.

[60] Varun and Chauhan, M.K. (2014). Carbon Footprints and Energy Estimation of the Sugar Industry, An Indian Case Study. Environmental Issues in Logistics and Manufacturing, Assessment of Carbon Footprints in Different Industrial Sectors. Springer Science and Business, Volume 2. pp 53-80. 